\title{
Comparison of native woody species for use as live stakes in streambank stabilization in the southeastern United States
}

\author{
A.E. Hunolt, E.F. Brantley, J.A. Howe, A.N. Wright, and C.W. Wood
}

\begin{abstract}
Live stakes are cuttings taken from dormant woody plant species used to establish riparian vegetation. Although many species may be suitable, black willow (Salix nigra) is the species of choice in streambank stabilization projects in the southeastern United States. Studies were conducted on four species native to the southeastern United States that have potential for success as live stakes. Black willow, silky willow (Salix sericea), silky dogwood (Cornus amomum), and Virginia sweetspire (Itea virginica) were evaluated for biomass differences among species, effect of soaking stakes in tap water for 48 hours prior to installation, and differences in survival attributed to season of harvest. The experiment was conducted at the Paterson Horticulture Greenhouse Complex, Auburn University, Alabama. Each species was established from live stakes and had 100\% survival when harvested during the dormant season. Total biomass of soaked and nonsoaked live stakes of silky dogwood was greater than soaked and nonsoaked black willow live stakes at nine months. This was driven by belowground biomass. At nine months, silky dogwood belowground biomass for nonsoaked stakes was greater than belowground biomass for black willow, silky willow, andVirginia sweetspire. Belowground biomass of soaked silky dogwood stakes was similar to belowground biomass of silky willow and greater than belowground biomass of black willow. Soaking live stakes collected in the dormant season for 48 hours resulted in only one significant total biomass difference between soaked and nonsoaked in the species silky dogwood at six months. After nine months of growth, there were no differences between soaked and nonsoaked live stake biomass. Virginia sweetspire, a shrub, consistently had less biomass, diameter, and height than the other species. However, the nine month root:shoot ratio of Virginia sweetspire was greater than both willow species and similar to silky dogwood. There was $0 \%$ survival of black willow, silky willow, and silky dogwood after six months when live stakes were harvested during the growing season irrespective of soaking treatment. Live stakes of Virginia sweetspire harvested in the growing season had a survival rate of $80 \%$ for soaked stakes and $67 \%$ for nonsoaked stakes. The four native species evaluated in this study became established and survived as live stakes. These species are candidates for use in riparian enhancement and restoration projects, which will assist with increasing riparian plant diversity.
\end{abstract}

Key words: bioengineering-live stake — restoration—riparian buffer

\begin{abstract}
Vegetation enhancement and restoration projects that assist in reclaiming the benefits of riparian ecosystems are well documented and accepted as an important natural mechanism to mitigate water pollution (Lowrance et al. 1985; Lee et al. 2000; Lee et al. 2003; Polyakov et al. 2005). Riparian vegetation plays an essential role in stream health and watershed function (Lowrance et al. 1984; Dosskey et al. 2010), providing food and habitat for terrestrial ani-
\end{abstract}

in some cases beneficial byproducts (Licht and Isebrands 2005). For example, inorganic forms of nitrogen $(\mathrm{N})$ and phosphorus $(\mathrm{P})$ may be assimilated by microbes or plants and converted into less mobile organic forms (Lockaby and Walbridge 1998) instead of being transported to a stream where they may promote eutrophication (Wells 2002).

Native plant species are recommended for riparian buffer plantings to restore or enhance a stable, natural stream and floodplain system. Native plants have traits that make them well adapted to local climate, soil conditions, and interactions with other local species. Specifically, native plants in riparian areas are resistant to stress associated with periodic flood and drought episodes, and thus are preferred for rapid establishment (Correl 2005; DuBois et al. 2009).

Riparian planting efforts often call for use of live stakes. Live stake plants are fast-growing deciduous hardwood cuttings of dormant branches installed along streambanks that are typically 0.5 to $1 \mathrm{~m}$ (1.6 to $3.3 \mathrm{ft})$ in length and $1 \mathrm{~cm}$ to $10 \mathrm{~cm}(0.4$ to 4 in) in diameter (Bir et al. 2002; DesCamp 2004; Logar and Scianna 2005; Greer et al. 2006; Li et al. 2006; Pezeshki and Shields 2006). Hoag (2009) noted that planting unrooted cuttings, such as live stakes, is the most common way to establish riparian woody species. Live stakes become established quicker than seeds and are less likely to wash away (Oklahoma Water Resource Board 2006). These characteristics make use of live stakes a cost-effective alternative to other bioengineering practices (Sotir and Fischenich 2003).

Installation of live stakes on streambanks has proven effective for repairing eroded banks, adding support to the soil, and minimizing pollutants that enter streams (Sotir and Fischenich 2003). Live stakes minimize erosion through promoting root growth, which stabilizes and controls shallow mass movement of soil by binding particles together and removing moisture from the

als; allochthonous food source for aqua animals; shade resulting in a more constant temperature regime that is less stressful for in-stream biota; and increased levels of dissolved oxygen $\left(\mathrm{O}_{2}\right)$, biogeochemical cycling, and streambank stabilization.

Riparian plants minimize pollutants entering a stream by physically slowing water and allowing solutes to settle (Gray and Sotir 1996) and by assisting transformation of those pollutants into less harmful and
Alicia E. Hunolt is a PhD student in the Department of Crop and Soil Environmental Sciences, Virginia Tech, Blacksburg, Virginia. Eve F. Brantley and Julie A. Howe are assistant professors, and C. Wes Wood is a professor in the Department of Agronomy and Soils, Auburn University, Alabama. Amy N. Wright is an associate professor in the Department of Horticulture, Auburn University, Alabama. 
soil (Gray and Sotir 1996). After establishment, live stakes reduce nonpoint source pollution by intercepting sediment and attached pollutants that would otherwise enter the stream (Sotir and Fischenich 2003; Logar and Scianna 2005). However, live stakes must establish roots, stems, and leaves before erosion is slowed (DesCamp 2004). Live stakes can dislodge and be swept downstream if not installed properly or if they have not rooted before a heavy rainfall event (Logar and Scianna 2005).

It is recommended that live stakes be harvested in the dormant season (Gray and Sotir 1996; Sotir and Fischenich 2003; Logar and Scianna 2005). Previous practice indicates that stakes should not dry out before planting, and it is recommended that they be soaked in water for a minimum of 48 hours in a cool place away from direct sunlight before installation (Logar and Scianna 2005; Tilley and Hoag 2008). Soaking live stakes prior to installation has been shown to increase survival and root:shoot ratio of willow species (Salicaceae) due to an increase in stem water content (Schaff et al. 2002, Tilley and Hoag 2008). Soaking also decreased mortality of willow live stakes when planted directly after removal from water (Schaff et al. 2002; Sotir and Fischenich 2003; Li et al. 2006; Pezeshki and Shields 2006). Although research has been conducted on willow, there is a lack of data in the literature on differences between survival and biomass of soaked and nonsoaked live stakes of other native species.

Many riparian buffer restoration projects predominantly use willow species live stakes (Greer et al. 2006; Li et al. 2006; Pezeshki and Shields 2006). Although black willow (Salix nigra) has the ability to rapidly establish from dormant cuttings (Pezeshki et al. 2005; Greer et al. 2006), it has been noted to have poor root strength, relatively lower roots per unit area than sycamore (Platanus occidentalis) and river birch (Betula nigra), and shallow roots that are mostly in the upper 20 to $30 \mathrm{~cm}$ (8 to $11.8 \mathrm{in}$ ) (Simon and Collison 2002). The use of willow species as live stakes has been adopted by several agencies even with a survival rate as low as 40\% (Schaff et al. 2003; Greer et. al. 2006; Pezeshki and Shields 2006). The low survival rate has been linked to flooding, drought, vertical location on bank, soil texture, and soil fertility (Pezeshki et al. 1998; Schaff et al. 2003; Greer et al. 2006; Li et al. 2006;
Pezeshki and Shields 2006; Tilley and Hoag 2008). Other trees and shrubs that root easily have not been well evaluated and may or may not outperform willow species (Darris 2002). For example, red osier dogwood (Cornus sericea) and Douglas spirea (Spiraea douglasii) have been identified as acceptable species for soil bioengineering (Darris 2002), but no published research on their establishment and survival could be found Examples of other recommended live stake species in the Southeast include silky dogwood (Cornus amomum), silky willow (Salix sericea), Virginia sweetspire (Itea virginica), buttonbush (Cephalanthus occidentalis), and elderberry (Sambucus canadensis) (Mitchell and Dyck 2000; Bir et al. 2002).

Though several different species of live stakes have been used in practice, combinations of them have rarely been observed in the same experiment. The combination of multiple species of live stakes in one experiment is important because it is likely the conditions will be more similar than repeating an experiment for each individual species. Black willow (Salix nigra), silky willow, silky dogwood, and Virginia sweetspire were selected for investigation due to previous experience that indicates their potential to thrive in moist conditions, ability to be planted as live stakes, and potential for longterm viability.

The objective of this study was to determine the effect of 48 hours of soaking in water before stake installation on survival and growth, evaluate and compare survival and growth of four native species of live stakes, and observe differences in survival based on season of installation.

\section{Materials and Methods}

Four species were studied: black willow, silky willow, silky dogwood, and Virginia sweetspire. Live stakes were cut using methods described by USDA NRCS (1996) from various locations on and around the Auburn University main campus in Auburn, Alabama, United States. Straight, healthy branches with a diameter of approximately $1 \mathrm{~cm}$ (0.4 in) were selected except for the shrub, Virginia sweetspire, from which branches were selected with a smaller diameter $(0.5 \mathrm{~cm}[0.2 \mathrm{in}])$ due to its smaller branch size. Shears were used to cut selected branches from trees. Smaller branches and leaves were removed from each large branch and cut so all that remained was a straight, smooth stick. Next, branches were cut into live stakes that measured $1.5 \mathrm{~m}$ (59.0 in) in length except for Virginia sweetspire, which was cut to a length of $46 \mathrm{~cm}$ (18.0 in). Each species was bundled and labeled to avoid confusing similar-looking stakes.

The basal end of all stakes were cut at a 45 degree angle to facilitate easier planting, while tops were cut flat. This eliminated confusion as to the correct end of the stake to soak and install. Immediately after being harvested, exactly one-half of each species (51 stakes) were placed in a bucket with basal ends submerged in $20 \mathrm{~cm}$ (7.8 in) of tap water. Buckets containing the soaked stakes were placed in a cooler at $4^{\circ} \mathrm{C}\left(39^{\circ} \mathrm{F}\right)$ for 48 hours before installation. Nonsoaked stakes were immediately installed by hand into microcosms that were under an outdoor 60\% woven shade cloth structure at the Paterson Horticulture Greenhouse Complex, Auburn, Alabama. The top of the structure was $3.4 \mathrm{~m}(11 \mathrm{ft})$ tall, sloping to $1.8 \mathrm{~m}(6 \mathrm{ft})$ along the short side, and a rain barrier of double layer $6 \mathrm{~mL}\left(0.4 \mathrm{in}^{3}\right)$ clear polyethylene plastic was present.

Microcosms were constructed using plastic tubs (Sterilite Corp., Townsend, Massachusetts) with dimensions of $48 \mathrm{~cm}$ (18 in) height, $86 \mathrm{~cm}$ (34 in) length, and $48 \mathrm{~cm}$ (18 in) width. Microcosms were filled with a mixture of $85 \%$ by volume sand $(124 \mathrm{~L}$ [33 gal]), 10\% topsoil (15 L [4 gal]), and 5\% organic matter (aged pine bark mulch) (9 L [2 gal]) substrate. Ten drainage holes were equally spaced along the sides, $0.1 \mathrm{~m}$ (4 in) from the bottom of the tub, with two each on the shorter sides and three each on the longer sides.

Plastic flagging tape was tied around each stake at the point where root collar diameter measurements were taken at the substrate surface to improve consistency of measurement. Plants were watered triweekly and 13-13-13 fertilizer (PeaFowl fertilizer, Piedmont Fertilizer Inc., Opelika, Alabama) was added biweekly at a concentration of $50 \mathrm{mg} \mathrm{L} \mathrm{L}^{-1}$ to ensure proper plant nutrition. Plants were irrigated until the point that water flowed freely from the drainage holes. Weeds were removed, and the stakes were monitored closely for problems such as weather damage or insect effects.

Dormant Season Planting. Trial 1 was conducted from March of 2010 to December of 2010 , and trial 2 was conducted from February of 2011 to November 
of 2011. In both trials, live stakes were cut and installed in the dormant season before bud break. Stakes were installed into the media of each microcosm until only half of the stake was exposed aboveground: 22.8 $\mathrm{cm}$ (9 in) for Virginia sweetspire and 30.5 $\mathrm{cm}$ (12 in) for the remaining species. Six stakes were installed in each microcosm in trial 1. Given the high survival rate observed in trial 1 , only four stakes were installed per microcosm in trial 2. A digital caliper (VWR LabShop, Batavia, Illinois) was used to measure the initial root collar diameter.

Destructive biomass harvests occurred at three, six, and nine months after stake installation. At each harvest date, 20 stakes (10 soaked and 10 nonsoaked) were collected for each species. Only living stakes were harvested. Height and diameter were measured for harvested stakes. Measurements were taken from the point of stake contact with the substrate (marked with flagging tape) to the tallest terminal bud. If a stake was no longer living, it was recorded as dead. The stakes were collected from the media with as many roots as possible intact and rinsed gently with water to remove soil. Stakes were separated into stem, leaf, and root components and placed in labeled paper bags. The labeled bags were dried at $70^{\circ} \mathrm{C}$ $\left(158^{\circ} \mathrm{F}\right)$ for 48 hours. After 48 hours, or until a constant weight was achieved, the samples were weighed and the results recorded. Aboveground biomass was recorded as stems plus leaves from above the initial point of stake contact with the substrate, and belowground biomass was all biomass below the initial point of stake contact with the substrate, including roots. Root:shoot ratio was calculated using belowground biomass and aboveground biomass.

Growing Season Planting. Live stakes were cut in July of 2011 during the growing season. The same methods for live stake selection and soaking were used as in the dormant season experiment. Height, diameter at root collar, and survival were determined at three and six months for every stake (Schaff et al. 2003; Pezeshki and Shields 2006).

Data Analysis. The experiment was a split plot design with species as main plots and soaking treatment as subplots. Microsoft Excel was used to consolidate the data. The statistical program SAS 9.2 was used to compare and analyze the data (SAS Institute Incorporated 2008). The Proc Univariate procedure was used to test for normality. The
PROC GLM-factorial procedure was used to compare main interaction effects, observe differences between soaking treatments within species, and detect differences among species. The level of significance was $\alpha=$ 0.05 using the Tukey-Kramer adjustment.

\section{Results and Discussion}

Influence of Soaking Live Stakes for 48 Hours in Water before Installation, Dormant Season Collection and Planting. There was no significant main effects interaction of the independent variables soaking and species for biomass or diameter at the three, six, and nine month harvests. There was a significant species-soaking interaction for height at three months $(p<0.01, F=3.51)$, but this interaction was not significant at the six or nine month harvests. Results below compare the soaked to nonsoaked live stakes within species.

Although commercial suppliers have suggested a 48-hour soaking period and previous research recommends some period of soaking (Phipps et al. 1983; Schaff et al. 2002; Balch 2008), it did not result in significant improvement in live stake survival or biomass increase for silky willow, black willow, or Virginia sweetspire live stakes cut in the dormant season. Silky dogwood soaked stakes had significantly greater total biomass (76.7 g [0.17 lb]) compared with the nonsoaked stakes $(58.2 \mathrm{~g}[0.13 \mathrm{lb}])$ at six months $(p<0.04, F=4.53)$ (figure 1$)$. This difference was driven primarily by the difference between belowground biomass of soaked $(38.3 \mathrm{~g}[0.08 \mathrm{lb}])$ and nonsoaked $(25.6 \mathrm{~g}$ $[0.06 \mathrm{lb}])$ stakes $(p<0.04, F=4.77)$. By nine months, there was no difference in total biomass between soaked and nonsoaked live stakes for any of the species evaluated.

Nonsoaked stakes in this study received adequate water immediately after collection and installation, which may have had the same effect as soaking for 48 hours. Ensuring live stakes do not dry out before installation is a common recommendation (USDA NRCS 1996; Logar and Scianna 2005). Soaking may not be required if live stakes are immediately installed at or below bankfull where they are in contact with water. Increasing the number of days that live stakes are soaked in water may influence biomass and survival. For example, Tilley and Hoag (2009) noted significantly greater root production after 70 days in peachleaf willow (Salix amygdaloides) cuttings that had been soaked for 14 days compared with nonsoaked cuttings. With only one exception, survival of peachleaf willow live stakes soaked for 14 days was better than nonsoaked stakes (Tilley and Hoag 2008).

Comparison of Live Stake Biomass among Species, Dormant Season Collection and Planting. All four species became established and had $100 \%$ survival when live stakes were cut in the dormant season. Results are presented as a comparison among species within the same soaking treatment.

There were significant differences among live stake species at three, six, and nine months in height, diameter, aboveground, belowground, and total biomass (tables 1, 2 , and 3). Nonsoaked and soaked stakes of black willow, silky willow, and silky dogwood had greater aboveground, belowground, and total biomass than Virginia sweetspire at the three-month harvest (table 1). Black willow below- and aboveground biomasses at three months were similar to findings by Greer et al. (2006) for control stakes (well watered, well drained) with diameter sizes of 1 and 5 $\mathrm{cm}$ (0.4 and 2 in).

At six months, nonsoaked and soaked stakes of Virginia sweetspire had less aboveground biomass than black willow, silky willow, and silky dogwood (table 2). Correspondingly, the six month total biomass of nonsoaked and soaked Virginia sweetspire live stakes were less than black willow, silky willow, and silky dogwood. Black willow belowground biomass was similar to Virginia sweetspire in both the nonsoaked and soaked treatments at the six month harvest.

By nine months, silky dogwood and silky willow live stakes had greater belowground and total biomass compared to black willow and Virginia sweetspire (table 3). Silky dogwood total biomass was greater than all other species, and this difference was significant for the nonsoaked treatment. Belowground biomass was the primary driver of total biomass differences among species at nine months in contrast to the three and six month results where aboveground biomass was the main influence.

Differences in aboveground, belowground, and total biomass were detected among species, and silky dogwood and silky willow appear to be the species of choice following nine months of establishment. Considering that most bioengineering associated with stream restoration occurs in the 


\section{Figure 1}

Mean ( \pm standard error) total biomass (g) of soaked and nonsoaked live stake cuttings at three, six, and nine months of four live stake species harvested and planted during the dormant season. Significant differences in biomass due to soaking, indicated by different letters, are within species harvested at the same time. The Tukey-Kramer adjustment was used to determine significance at $\alpha=0.05$.

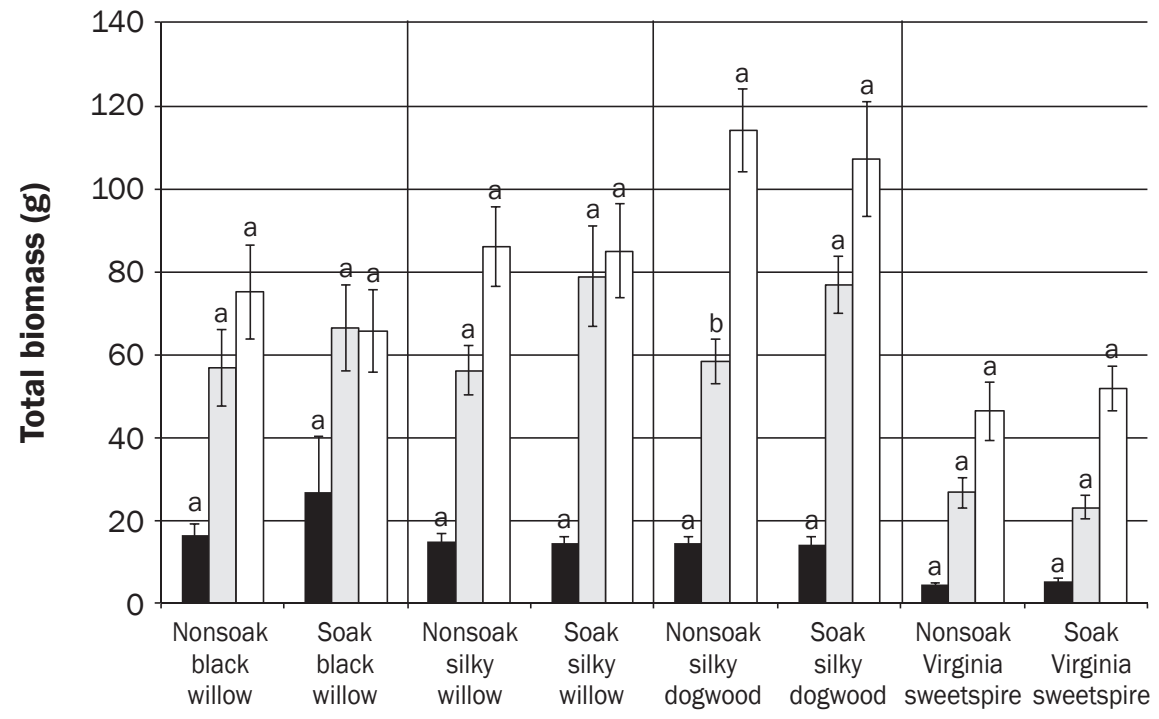

\section{Cutting}

\section{Legend}

3 months 6 months

9 months may be enhanced by greater belowground biomass that provides resistance to drought stress through improved ability to intersect water tables.

Root:Shoot Ratio No differences among species were observed for root:shoot ratios at three months regardless of soaking treatment (table 4). Black willow root:shoot ratios at three months were similar to findings by Greer et al. (2006) for control stakes (well watered, well drained) with diameter sizes of 1 and $5 \mathrm{~cm}$ (0.4 and 2 in). Silky willow's root:shoot ratio was greater than black willow and less than silky dogwood and Virginia sweetspire, but these differences were not significant at six months. At six and nine months, the root:shoot ratios of Virginia sweetspire and silky dogwood were greater than black willow for both soaked and nonsoaked stakes. Developing root:shoot ratio relationships for live stake species may assist in determining root production for field studies where destructive harvesting of belowground biomass may be difficult or undesirable (Monk 1966).

The establishment and survival of willow and dogwood species was expected based on prior experience and research. Numerous field and greenhouse studies with black willow suggest it is a good option for use as live stakes (Greer et al. 2006; Li et. al. 2006; Pezeshki and Shields 2006). Barrett et al. (2006) noted dogwood and willow species that had been planted as live stakes or poles (larger dormant cuttings) were the only species that survived five years after the implementation of a bioengineering project dormant season, greater belowground biomass at nine months of silky dogwood and silky willow may prove beneficial for stream stabilization at a critical time when projects face increased fall and winter stream flows. Roots in a streambank provide increased soil strength and resistance to erosion (Barrett et al. 2006), and selecting live stake species that have greater belowground biomass may assist in stabilizing streambanks more rapidly than those with less belowground biomass. Additionally, long-term survival

\section{Table 1}

Means of leaf, stem, aboveground (leaf + stem), belowground, and total (aboveground + belowground) biomass; diameter; and height of four live stake species three months following dormant season collection and planting in microcosms.

\begin{tabular}{|c|c|c|c|c|c|c|c|}
\hline $\begin{array}{l}\text { Treatment } \\
\text { and species }\end{array}$ & $\begin{array}{l}\text { Leaf } \\
\text { biomass (g) }\end{array}$ & $\begin{array}{l}\text { Stem } \\
\text { biomass (g) }\end{array}$ & $\begin{array}{l}\text { Aboveground } \\
\text { biomass (g) }\end{array}$ & $\begin{array}{l}\text { Belowground } \\
\text { biomass (g) }\end{array}$ & $\begin{array}{l}\text { Total } \\
\text { biomass (g) }\end{array}$ & $\begin{array}{l}\text { Diameter } \\
(\mathrm{mm})\end{array}$ & $\begin{array}{l}\text { Height } \\
\text { (cm) }\end{array}$ \\
\hline \multicolumn{8}{|l|}{ Nonsoaked stakes } \\
\hline Black willow & $2.5 a$ & $6.4 a$ & $8.9 a$ & 7.3a & $16.2 a$ & 7.5a & $67.7 a$ \\
\hline Silky willow & $2.3 a$ & $5.4 a$ & $7.7 a$ & $7.0 \mathrm{a}$ & $14.7 a$ & $6.8 a b$ & $58.5 a b$ \\
\hline Silky dogwood & $2.3 a$ & 4.3ab & $6.7 a$ & $7.8 \mathrm{a}$ & $14.5 a$ & $6.8 a b$ & $51.9 b$ \\
\hline Virginia sweetspire & $0.6 b$ & $1.5 b$ & $2.1 b$ & $2.3 b$ & $4.4 b$ & $4.7 b$ & $27.4 c$ \\
\hline \multicolumn{8}{|l|}{ Soaked stakes } \\
\hline Black willow & $1.8 \mathrm{bc}$ & $4.2 \mathrm{a}$ & $6.0 \mathrm{a}$ & $7.2 \mathrm{a}$ & 13.3a & $7.2 \mathrm{a}$ & $58.3 b$ \\
\hline Silky willow & $2.9 a$ & $4.8 \mathrm{a}$ & $7.6 a$ & $6.7 a$ & $14.4 \mathrm{a}$ & $6.5 a$ & 77.9a \\
\hline Silky dogwood & $2.0 a b$ & $4.0 \mathrm{a}$ & $6.0 \mathrm{a}$ & $8.0 a$ & $13.9 a$ & $7.2 \mathrm{a}$ & $49.2 b$ \\
\hline Virginia sweetspire & $0.95 c$ & $1.7 \mathrm{~b}$ & $2.6 b$ & $2.8 b$ & $5.4 b$ & $5.4 a$ & $27.3 c$ \\
\hline
\end{tabular}

Note: Values within the same column within the same soaking treatment followed by different letters are significantly different by Tukey-Kramer adjustment at $\alpha=0.05$. 
Table 2

Means of leaf, stem, aboveground (leaf + stem), belowground, and total (aboveground + belowground) biomass; diameter; and height of four live stake species at six months following dormant season collection and planting in microcosms.

\begin{tabular}{|c|c|c|c|c|c|c|c|}
\hline $\begin{array}{l}\text { Treatment } \\
\text { and species }\end{array}$ & $\begin{array}{l}\text { Leaf } \\
\text { biomass (g) }\end{array}$ & $\begin{array}{l}\text { Stem } \\
\text { biomass (g) }\end{array}$ & $\begin{array}{l}\text { Aboveground } \\
\text { biomass (g) }\end{array}$ & $\begin{array}{l}\text { Belowground } \\
\text { biomass (g) }\end{array}$ & $\begin{array}{l}\text { Total } \\
\text { biomass (g) }\end{array}$ & $\begin{array}{l}\text { Diameter } \\
(\mathrm{mm})\end{array}$ & $\begin{array}{l}\text { Height } \\
\text { (cm) }\end{array}$ \\
\hline \multicolumn{8}{|l|}{ Nonsoaked stakes } \\
\hline Black willow & $13.5 a$ & $27.5 a$ & $41.0 a$ & $15.8 \mathrm{ab}$ & $56.7 a$ & $12.6 a$ & $135.6 a$ \\
\hline Silky willow & 12.3ab & $22.2 a$ & $34.8 a$ & $21.3 a$ & $56.1 a$ & $11.2 a b$ & $127.3 a$ \\
\hline Silky dogwood & $12.6 a$ & 18.4ab & $32.6 a$ & $25.6 a$ & $58.2 a$ & 10.6ab & $109.9 a$ \\
\hline Virginia sweetspire & $8.0 \mathrm{~b}$ & $7.8 b$ & $15.8 b$ & $10.8 b$ & $26.6 b$ & $9.3 b$ & $57.5 b$ \\
\hline \multicolumn{8}{|l|}{ Soaked stakes } \\
\hline Black willow & $16.4 a$ & $33.4 a$ & $49.8 a$ & $16.6 \mathrm{bc}$ & $66.4 a$ & $11.3 a$ & $139.1 \mathrm{a}$ \\
\hline Silky willow & $15.2 \mathrm{a}$ & $27.3 a$ & $41.7 a$ & $28.6 a b$ & $70.3 a$ & $11.2 \mathrm{a}$ & $137.2 \mathrm{a}$ \\
\hline Silky dogwood & $14.0 \mathrm{a}$ & $26.5 a$ & $38.4 a$ & $38.3 a$ & $76.7 a$ & $16.6 a$ & $116.0 a$ \\
\hline Virginia sweetspire & $7.5 \mathrm{~b}$ & $6.3 b$ & $13.9 b$ & $9.2 \mathrm{c}$ & $23.1 \mathrm{~b}$ & $9.1 \mathrm{a}$ & $58.3 b$ \\
\hline
\end{tabular}

Note: Values within the same column within the same soaking treatment followed by different letters are significantly different by Tukey-Kramer adjustment at $\alpha=0.05$.

\section{Table 3}

Means of leaf, stem, aboveground (leaf + stem), belowground, and total (aboveground + belowground) biomass; diameter; and height of four live stake species at nine months following dormant season collection and planting in microcosms.

\begin{tabular}{|c|c|c|c|c|c|c|c|}
\hline $\begin{array}{l}\text { Treatment } \\
\text { and species }\end{array}$ & $\begin{array}{l}\text { Leaf } \\
\text { biomass (g) }\end{array}$ & $\begin{array}{l}\begin{array}{l}\text { Stem } \\
\text { biomass (g) }\end{array} \\
\end{array}$ & $\begin{array}{l}\text { Aboveground } \\
\text { biomass (g) } \\
\end{array}$ & $\begin{array}{l}\text { Belowground } \\
\text { biomass (g) }\end{array}$ & $\begin{array}{l}\text { Total } \\
\text { biomass (g) }\end{array}$ & $\begin{array}{l}\text { Diameter } \\
(\mathrm{mm})\end{array}$ & $\begin{array}{l}\text { Height } \\
\text { (cm) }\end{array}$ \\
\hline \multicolumn{8}{|l|}{ Nonsoaked stakes } \\
\hline Black willow & $3.7 \mathrm{~b}$ & $45.1 a$ & $48.8 a$ & $26.3 b$ & $75.1 \mathrm{bc}$ & $16.6 a$ & $161.7 a$ \\
\hline Silky willow & $3.4 b$ & $37.3 a$ & $40.7 a$ & $45.4 b$ & $86.0 \mathrm{~b}$ & $11.6 a$ & $136.6 a$ \\
\hline Silky dogwood & $10.0 a$ & 27.6ab & $37.6 a b$ & $76.4 a$ & $114.0 a$ & $18.6 a$ & $108.7 b$ \\
\hline Virginia sweetspire & $6.2 \mathrm{ab}$ & $13.0 \mathrm{~b}$ & $19.1 \mathrm{~b}$ & $27.0 \mathrm{~b}$ & $46.2 c$ & $9.7 a$ & $67.0 \mathrm{c}$ \\
\hline \multicolumn{8}{|l|}{ Soaked stakes } \\
\hline Black willow & $3.2 \mathrm{ab}$ & $33.5 a$ & $37.8 a$ & $27.1 b$ & $65.5 b$ & $13.1 a$ & $146.7 a$ \\
\hline Silky willow & $2.2 b$ & $30.2 a$ & $32.3 a b$ & $51.8 a b$ & $84.8 a b$ & $12.7 a$ & $140.3 a$ \\
\hline Silky dogwood & $5.7 a b$ & $27.1 a$ & $37.9 a$ & $73.2 \mathrm{a}$ & $107.1 a$ & $12.3 a$ & $106.8 b$ \\
\hline Virginia sweetspire & $6.8 a$ & $11.1 \mathrm{~b}$ & $17.9 b$ & $33.9 b$ & $51.8 \mathrm{~b}$ & $10.3 a$ & $66.1 \mathrm{c}$ \\
\hline
\end{tabular}

Note: Values within the same column within the same soaking treatment followed by different letters are significantly different by Tukey-Kramer adjustment at $\alpha=0.05$.

in Ohio. Black willow consistently had less biomass than the other species evaluated, except for Virginia sweetspire, and the root:shoot ratio of black willow was less than that of other species evaluated and significantly less than silky dogwood for both soaked and nonsoaked treatments (table 4). Visual inspections at times of harvest supported observations by others that black willow had fewer roots per unit area than the other species evaluated in this project and these small diameter roots were generally found in the top 20 to $30 \mathrm{~cm}$ of soil (Simon and Collison 2002) (figure 2).

Virginia sweetspire performed well as a live stake, although it had less total biomass, significantly less height, and smaller diameter than the other species at three, six, and nine months (tables 1, 2, and 3). This difference in biomass, height, and diameter is expected as Virginia sweetspire's growth habit is a medium shrub and the other species are considered either large shrubs (silky dogwood) or trees (willow species) (Dirr 1998; Lady Bird Johnson Wildlife Center 2012). At nine months, belowground biomass of Virginia sweetspire was significantly less than silky dogwood and similar to the willow species (table 3 ).

The excellent survival and growth of the four species observed supports incorporating a combination of these species for riparian restoration efforts in the Southeast rather than relying on one species, such as black willow. A diversity of species provides benefits including varied types of root systems that may improve soil stability by occupying the soil at different angles and depths (Kutschera and Lichtenegger 1997; Stokes et al. 2009). Species diversity of riparian vegetation has been noted to increase water quality, terrestrial wildlife, and biodiversity (Kauffman and Krueger 1984; Bjornn and Reiser 2008). By using riparian vegetation plantings that have a wide range of shade, habitat, and pollutant control capabilities, stream degradation can be slowed (Correll 2005; Bir and Conner 2010).

Harvest Timing. Cutting and planting live stakes in the dormant season resulted in $100 \%$ survival for all for species evaluated in the experiment (data not shown). Survival rates, height, and diameter of live stakes cut in the growing season were lower than stakes cut in the dormant season regardless 


\section{Table 4}

Live stake comparison of root:shoot ratio among species at three, six, and nine months following collection and installation in microcosms during the dormant season.

\begin{tabular}{llll}
\hline $\begin{array}{l}\text { Treatment } \\
\text { and species }\end{array}$ & Months & $\mathbf{9}$ \\
\cline { 2 - 4 } $\begin{array}{l}\text { Nonsoaked stakes } \\
\text { Black willow }\end{array}$ & $1.03 \mathrm{a}$ & $0.46 \mathrm{~b}$ & $0.56 \mathrm{~b}$ \\
Silky willow & $1.03 \mathrm{a}$ & $0.60 \mathrm{ab}$ & $1.37 \mathrm{~b}$ \\
Silky dogwood & $1.45 \mathrm{a}$ & $0.81 \mathrm{a}$ & $2.90 \mathrm{a}$ \\
$\quad$ Virginia sweetspire & $1.28 \mathrm{a}$ & $0.84 \mathrm{a}$ & $2.06 \mathrm{a}$ \\
Soaked stakes & & & \\
$\quad$ Black willow & $1.30 \mathrm{a}$ & $0.35 \mathrm{~b}$ & $0.67 \mathrm{~b}$ \\
Silky willow & $0.89 \mathrm{a}$ & $0.66 \mathrm{ab}$ & $1.69 \mathrm{ab}$ \\
Silky dogwood & $1.38 \mathrm{a}$ & $0.99 \mathrm{a}$ & $2.40 \mathrm{a}$ \\
Virginia sweetspire & $1.18 \mathrm{a}$ & $0.83 \mathrm{a}$ & $2.12 \mathrm{a}$ \\
\hline
\end{tabular}

Note: Root:shoot ratio is defined as the belowground (root) biomass divided by aboveground (leaves and stem) biomass. Values within the same column within the same soaking treatment followed by different letters are significantly different by Tukey-Kramer adjustment at $\alpha=0.05$. of soaking treatment (table 5). These results confirm previous research on timing of live stake installation in the dormant season to maximize establishment and survival (Darris 2002; Shafer and Lee 2003; Sotir and Fischenich 2003; Logar and Scianna 2005; Balch 2008.). Virginia sweetspire had the highest survival rate after three months and was the only species that survived to six months. This may be related to its ability to perform well in a drought environment (Dylewski et al. 2012; Baily 2009).

Because of the high levels of mortality in black willow, silky willow, and silky dogwood, a growing season harvest is not recommended for the installation of live stakes. If a growing season harvest cannot be avoided, the use of Virginia sweetspire may

\section{Figure 2}

Belowground biomass of (a) black willow, (b) silky willow, (c) silky dogwood, and (d) Virginia sweetspire, which were soaked prior to installation.

(a)

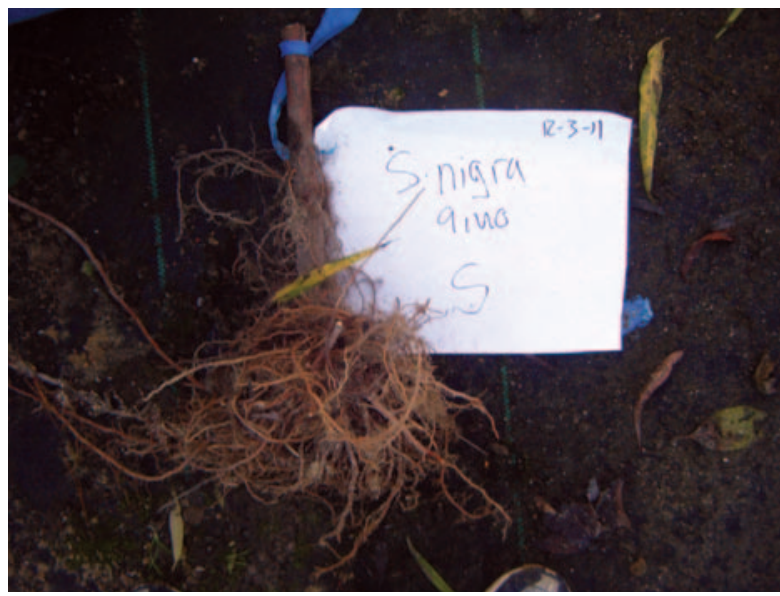

(c)

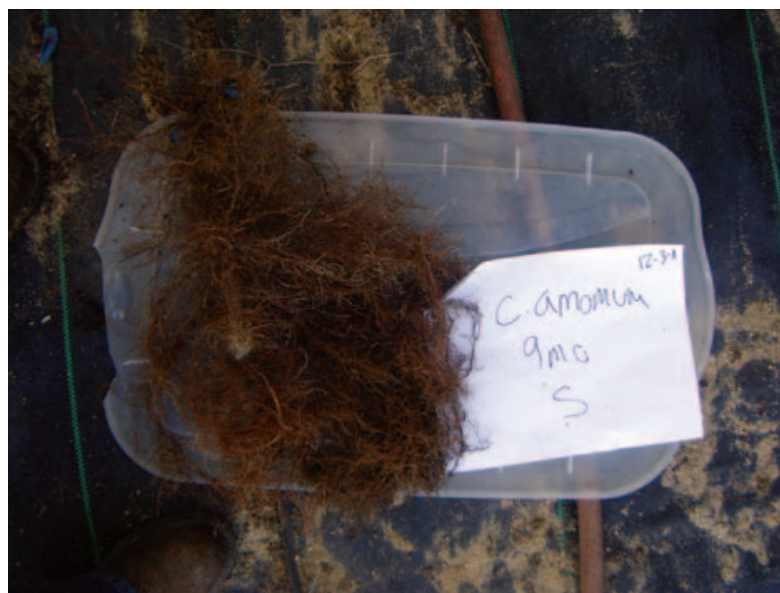

(b)

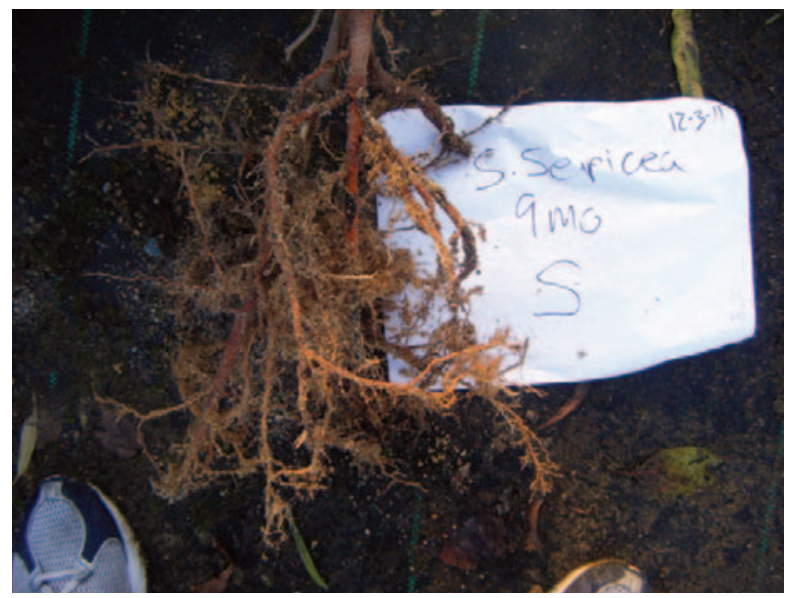

(d)

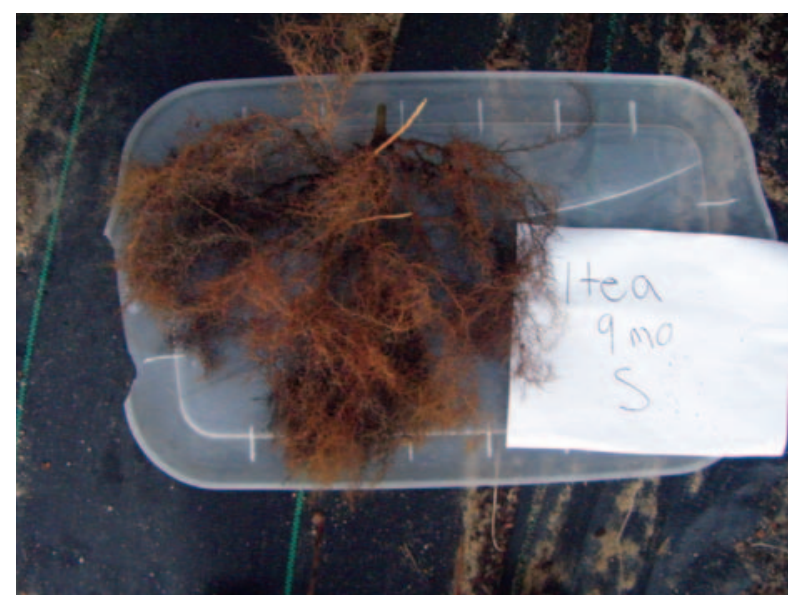


Table 5

Growing season harvest survival of four soaked and nonsoaked live stake species at three and six months after planting. Results presented as number alive, number dead, and percentage alive.

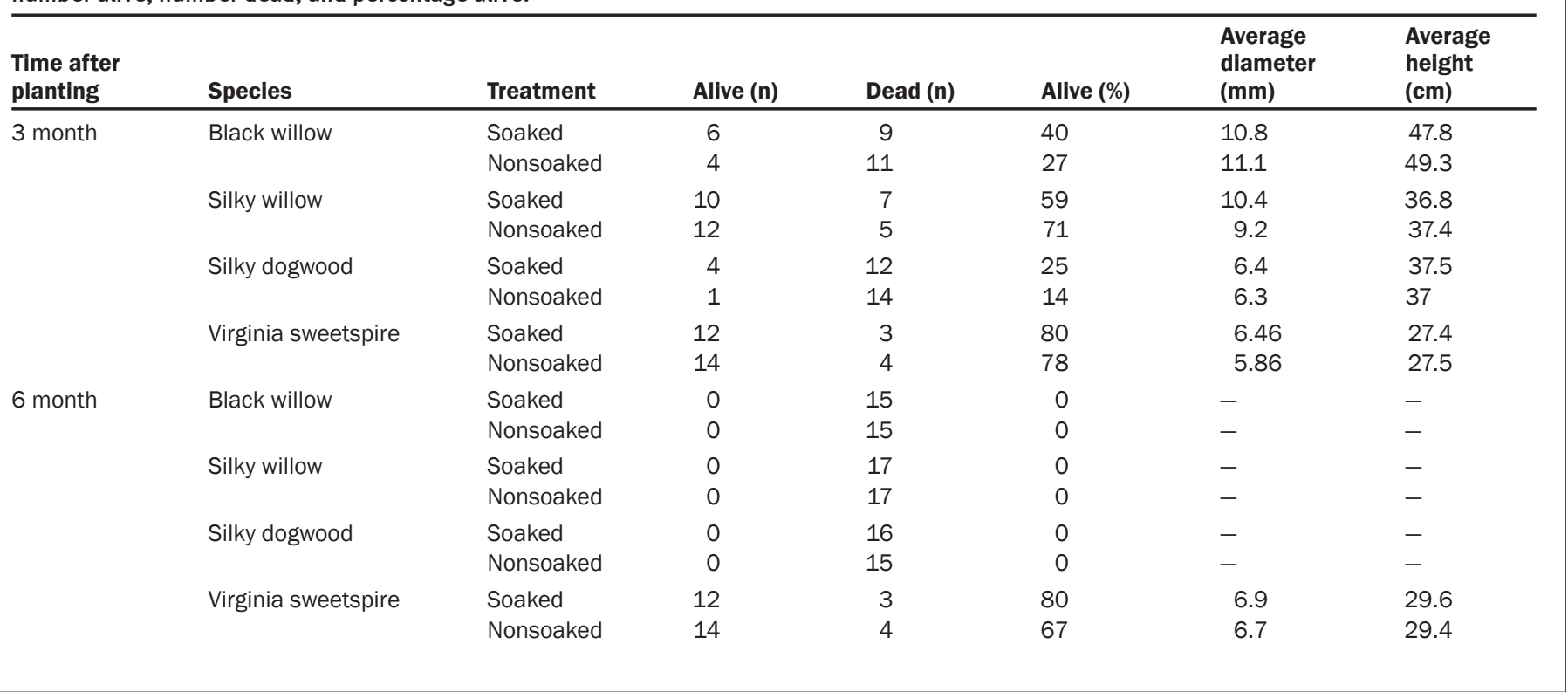

assist with establishing vegetation until the following dormant season with the understanding that the stakes must intersect stream baseflow so that they do not dry out after installation. A longer soaking period may also result in increased survival of live stakes cut in the growing season. A seven-day soaking period for nondormant cuttings that are well watered, but not inundated, enhanced survival and early development (bud flush) (Pezeshki et al. 2005).

\section{Summary and Conclusion}

This study evaluated the growth and survival of black willow, silky willow, silky dogwood, and Virginia sweetspire live stakes that are native plants commonly found in riparian corridors in the southeastern United States. Results indicate that soaking live stakes in water for 48 hours may not be required for survival and establishment as long as stakes do not dry out prior to establishment and are installed below bankfull where there is adequate soil moisture. Significant differences in biomass and root:shoot ratio among the species were observed, and the season of live stake harvest is critical for live stake survival.

When live stakes were harvested in the dormant season, there was no difference between soaked and nonsoaked survival or total biomass at the three, six, and ninemonth harvest for all four species with one exception. Soaked live stakes of silky dogwood were significantly greater in total biomass than nonsoaked live stakes at six months. By nine months, however, there was no difference between the live stakes in each soaking treatment. All live stakes harvested in the dormant season had 100\% survival regardless of soaking treatment.

Silky dogwood and silky willow had greater belowground and total biomass after nine months than black willow and Virginia sweetspire. Greater belowground biomass may improve the ability of these species to provide streambank soil stabilization and increase ability of a live stake to survive droughty conditions through a healthy root system that may access lower water tables. Silky dogwood and Virginia sweetspire had greater root:shoot ratios than the willow species. Virginia sweetspire had the least biomass compared with the other species, which is expected as it is a medium shrub. The smaller aboveground biomass and high root:shoot ratio of Virginia sweetspire makes it an attractive live stake species for stream restoration projects that may desire lower-growing vegetation, such as public parks and golf courses.

A dormant season collection and installation is recommended for these live stake species based on low survival rates during growing season installation. If a growing season harvest of live stakes is necessary,Virginia sweetspire was the only species that survived to six months, and soaked live stakes had an $80 \%$ survival rate.

Possible factors to be investigated in future research may include variable time of soaking stakes, use of rooting hormone, and whether or not those factors affect growing season harvest results. Future studies may also incorporate other native live stake species, such as elderberry, buttonbush, river birch, sycamore, and ninebark (Physocarpus opulifolius).

Every restoration project is unique and requires its own analysis before implementation. Therefore, recommendations on live stake species should be determined by site-specific needs, such as shade tolerance or aesthetics. A mixture of black willow, silky willow, silky dogwood, and Virginia sweetspire live stakes may be used to achieve an aesthetically appealing riparian corridor and to increase biodiversity along streams. Results from this study and future studies will provide landowners and resource managers with recommendations for low-cost and effective alternatives for stream and river riparian vegetation plantings.

\section{References}

Baily, A.L. 2009. Post-transplant Irrigation Scheduling of Native Deciduous Shrub Taxa. Master's thesis, Auburn University.

Balch, P. 2008. Instructions for Harvesting, Transportation, and Storing Live Cuttings for Vegetating and Stabilizing Streambanks. Topeka, KS: Wildhorse Riverworks Inc.

Barrett, K., W. Goldsmith, and M. Silva. 2006. Integrated bioengineering and geotechnical treatments for streambank restoration and stabilization along a landfill. Journal of Soil and Water Conservation 61(3):144-153.

Bir, J.C., and J. Conner. 2010. Conservation Specifications. CS-UT-231-livestakes. Washington, DC: USDA.

Bir, R., J. Calabria, and J. Conner. 2002. Hardwood Cuttings for Erosion Control. Raleigh, NC: North Carolina State University Extension. 
Bjornn, T.C., and D.W. Reiser. 2008. Influences of forest and rangeland management on salmonid fishes and their habitats. Terrestrial Wildlife American Fisheries Society Special Publication 19:389-423.

Correll, D.L. 2005. Principles of planning and establishment of buffer zones. Ecological Engineering 24:433-439.

Darris, D.C. 2002. Native Shrubs as a Supplement to the Use of Willows as Live Stakes and Fascines in Western Oregon and Western Washington. Technical Notes, 1-17. Portland OR: Natural Resources Conservation Service.

DesCamp, W. 2004. Collecting, Installing, Storing and Caring for Live Stakes. ESRM 412 Native Plant Production. Seattle, WA: University of WashingtonCollege of Natural Resources.

Dirr, M.A. 1998. Manual of Woody Landscape Plants, 5th ed. Champaign, Illinois: Stipes Publishing.

Dosskey, M., P. Vidon, N. Gurwick, C. Allen, T. Duvall, and R. Lowrance. 2010. The role of riparian vegetation in protecting and improving water quality. Journal of the American Water Resources Association 46(2):261-277.

DuBois, L., J. Latimer, B. Appleton, and D. Close 2009. America's Anniversary Garden: Native Plants. Blacksburg,VA:Virginia Cooperative Extension.

Dylewski, K.L., A.N. Wright, K.M. Tilt, and C. LeBleu. 2012. Effect of previous flood exposure on flood tolerance and growth of three landscape shrub taxa subjected to repeated short-term flooding. HortTechnology 21(4):461-465.

Gray, D.H., and R.B. Sotir. 1996. Biotechnical and Soil Bioengineering Slope Stabilization, 1st edition. New York: John Wiley and Sons.

Greer, E., S.R. Pezeshki, and F.D. Shields. 2006. Influences of cutting diameter and soil moisture on growth and survival of black willow, Salix nigra. Journal of Soil and Water Conservation 61(5):311-323.

Hoag, C.J. 2009. Vertical Bundles: A Streambank Bioengineering Treatment to Establish Willows and Dogwoods on Streambanks. Technical Note, USDA Natural Resources Conservation Service. Plant Material No. 53. Boise, ID and Salt Lake City, UT: USDA Natural Resources Conservation Service.

Kauffman, J.B., and W.C. Krueger. 1984. Livestock impacts on riparian ecosystems and streamside management implications-A review. Journal of Range Management 37(5):430-438

Kutschera, L., and E. Lichtenegger. 1997. Wurzeln. Bewurzelung von Pflanzen in Verschiedenen Lebensräumen. Stapfia 49, Land Oberösterreich, OÖ. Landesmuseum, Linz, Austria.

Lady Bird Johnson Wildflower Center. 2012. Native Plant Information Network. Austin, TX: The University of Texas of Austin. http://www.wildflower.org/plants/.

Lee, K., T.M. Isenhart, R.C. Schultz, and S.K. Mickelson. 2000. Multispecies riparian buffers trap sediment and nutrients during rainfall simulations. Journal of Environmental Quality 29(4):1200-1205.

Lee, K.H., T.M. Isenhert, and R.C. Schultz. 2003. Sediment and nutrient removal in an established multispecies riparian buffer. Journal of Soil and Water Conservation 58(1):1-8.

Li, S., S.R. Pezeshki, and F.D. Shields. 2006. Partial flooding enhances aeration in adventitious roots of black willow (Salix nigra) cuttings. Journal of Plant Physiology 163:619-628.

Licht, L.A., and J.G. Isebrands. 2005. Linking phytoremediated pollutant removal to biomass economic opportunities. Biomass and Bioenergy 28(2):203-218.

Lockaby, B.G., and M.R. Walbridge. 1998. Biogeochemistry. In Southern Forested Wetlands Ecology and
Management, eds. M.G. Messina and W.H. Conner, 149 172. Boca Raton, FL: Lewis Publishers.

Logar, R., and J. Scianna. 2005. Improving the Establishment of Willow Cuttings in Riparian Areas. Forestry Technical Note. No. MJ-25. Washington, DC: USDA Natural Resources Conservation Service.

Lowrance, R., R. Leonard, and J. Sheridan. 1985. Managing riparian ecosystems to control nonpoint source pollution. Journal of Soil and Water Conservation 40(1):87-91.

Lowrance, R., R. Todd, J. Fail Jr., O. Hendrickson Jr. R. Leonard, and L. Asmussen. 1984. Riparian forest as nutrient filters in agricultural watersheds. Bioscience 34(6):374-377

Mitchell, J., and L. Dyck. 2000. Materials and Techniques for Live Staking Plants onto Reservoir Shorelines. Southern Division of American Fisheries Societymidyear meeting Savannah, GA.

Monk, C. 1966. Ecological importance of root/shoot ratios. Bulletin of the Torrey Botanical Club 93(6):402-206.

Oklahoma Water Resource Board. 2006. Demonstration Project: Mitigation of Non-point Source Impact to Littoral Zone of Lake Carl Blackwell. Payne County Oklahoma. FY-01 319(h) Task \#01-003 CA \# C9-996100-07 Project 3, funded by the Environmental Protection Agency. Oklahoma City, OK: Oklahoma Water Resource Board.

Pezeshki, R.S., H.P. Anderson, and F.D. Shields. 1998. Effects of soil moisture regimes on growth and survival of black willow (Salix nigra) posts (cuttings). The Society of Wetland Scientists: Wetlands 18(3):460-470.

Pezeshki, S.R., C.E. Brown, J.M. Elcan, and F.D. Shields. 2005. Responses of non-dormant black willow (Salix nigra) cuttings to preplanting soaking and soil moisture. Restoration Ecology 10:1-7.

Pezeshki, R.S., and F.D. Shields. 2006. Black willow cutting survival in streambank plantings, southeastern United States. Journal of the American Water Resources Association 42(1):191-200.

Phipps, H.M., E.A. Hansen, and A.S. Fege. 1983. Preplant Soaking of Dormant Populus Hardwood Cuttings. Research Paper NC-241.9. St Paul, MN: USDA Forest Service. North Central Forest Experiment Station.

Polyakov, A., A. Fares, and M.H. Ryder. 2005. Precision riparian buffers for the control of nonpoint source pollutant loading into surface water: A review. Environmental Reviews 13(3):129-144.

SAS Institute Inc. 2008. SAS 9.2 Enhanced Logging Facilities. Cary, NC: SAS Institute Inc.

Schaff, S.D., S.R. Pezeshki, and F.D. Shields. 2002. Effects of pre-planting soaking on growth and survival of black willow cuttings. Restoration Ecology 10(2):267-274.

Schaff, S.D., S.R. Pezeshki, and F.D. Shields. 2003. Effect of soil conditions on survival and growth of black willow cuttings. Environmental Management 31(6):748-763.

Shafer, D., and A.A. Lee. 2003. Willow stake installation: Example contract specifications. EMRRP Technical Notes Collection (ERDC TN-EMRRP-ER-02) Vicksburg, MS: US Army Engineer Research and Development Center.

Simon, A., and A.J.C. Collision. 2002. Quantifying the mechanical and hydrologic effects of riparian vegetation on streambank stability. Earth Surface Processes and Landforms 27:527-546.

Sotir, R.B., and J.C. Fischenich. 2003. Livestake and Joint Planting for Streambank Erosion Control. EMRRP Technical Notes Connection, ERDC TN-EMRRP-SR-35. Vicksburg, MS: US Army Engineer Research and Development Center.
Stokes, A., C. Atger, A.G. Bengough, T. Fourcaud, and R.C. Sidle. 2009. Desirable plant root traits for protecting natural and engineered slopes against landslides. Plant and Soil 324:1-30.

Tilley, D.J., and J.C. Hoag. 2008. Effects of pre-plant soaking treatments on hardwood cuttings of peachleaf willow. Riparian/Wetland Project Information Series. Number 24. Aberdeen, ID: USDA Natural Resource Conservation Service, Aberdeen Plant Materials Center.

Tilley, D.J., and J.C. Hoag. 2009. Evaluation of fall versus spring dormant planting of hardwood willow cuttings with and without soaking treatment. Native Plants Journal 10(3):288-294

USDA NRCS (Natural Resources Conservation Service) 1996. Streambank and Shoreline protection. Part 650 Chapter 16. Engineering field handbook. Washington, DC: USDA.

Wells, G.W. 2002. Biotechnical Streambank Protection: The Use of Plants to Stabilize Streambanks. USDA Forest Service, National Agroforestry Center. Agroforestry Notes. Lincoln, NE: University of Nebraska - Lincoln. 